\title{
Karakteristik Penderita Dakriosistitis di Pusat Mata Nasional Rumah Sakit Mata Cicendo
}

\author{
M. Rinaldi Dahlan, Kautsar Boesoirie, Angga Kartiwa, Shanti F. Boesoirie, Helda Puspitasari \\ Departemen Ilmu Kesehatan Mata Fakultas Kedokteran Universitas Padjadjaran \\ Pusat Mata Nasional Rumah Sakit Mata Cicendo Bandung
}

\begin{abstract}
Abstrak
Infeksi sistem lakrimal yang paling umum adalah dakriosistitis. Infeksi biasanya didahului oleh obstruksi duktus nasolakrimalis dan dapat terjadi pada semua kelompok usia. Tujuan penelitian ini adalah mencari jumlah kasus, karakteristik demografi dan klinis, serta pengelolaan dakriosistitis di RS Mata Cicendo periode 1 Maret 2014 sampai dengan 30 September 2014. Metode yang digunakan, yaitu dengan meninjau secara retrospektif rekam medis penderita dakriosistitis di Rumah Sakit Mata Cicendo Bandung selama periode 1 Maret 2014 sampai dengan 30 September 2014. Jumlah kasus, karakteristik demografi dan klinis, serta manajemen kasus ini ditinjau. Terdapat 13 pasien (13 mata) yang didiagnosis sebagai dakriosistitis. Sebagian besar pasien adalah perempuan. Usia rata-rata adalah 41,3 tahun. Semua kasus adalah unilateral. Infeksi akut adalah dominan dari pada infeksi kronik. Sebelas kasus diterapi dengan obat-obatan dan dua kasus kronik diterapi dengan dacryocystorhinostomy (DCR). Sebagai kesimpulan, terdapat 13 pasien (13 mata) yang didiagnosis sebagai dakriosistitis akut dan kronik. Sebagian besar pasien adalah wanita di usia pertengahan, kasus unilateral, serta penatalaksanaan dengan obatobatan dan DCR. [MKB. 2017;49(4):281-6]
\end{abstract}

Kata kunci: Dakriosistitis, karakteristik, penatalaksanaan

\section{Characteristics of Dacryocystitis Patients in National Eye Center of Cicendo Eye Hospital}

\begin{abstract}
The most common infection of the lacrimal apparatus is dacryocystitis. Infection is usually preceded by obstruction of the nasolacrimal duct and may occur in any age group.The aim of this study was to discover number of cases, demographic and clinical characteristics, and management of dacryocystitis in Cicendo Eye Hospital during the period of March 1, 2014 to September 30, 2014.Medical records of dacryocystitis patients attending Cicendo Eye Hospital during the period of March 1, 2014 to September 30,2014 were retrospectively reviewed. Number of cases, demographic and clinical characteristics, and the management of these cases were reviewed.There were 13 patients (13 eyes) diagnosed as suffering from dacryocystitis with most of them were female patients (92.31\%). The mean age was 41.3 years old. All cases were unilateral. Acute infection was predominant than chronic infection. Eleven cases were treated with medication therapy and two chronic cases were treated with dacryocystorhinostomy (DCR). Hence, there were 13 patients (13 eyes) diagnosed as acute and chronicdacryocystitis. Most of them were middle age female patients with unilateral cases and treated with medication therapy and DCR. [MKB. 2017;49(4):281-6]
\end{abstract}

Key words: Characteristic, dacryocystitis, treatment

Korespondensi: Dr. M. Rinaldi Dahlan, dr., Sp.M, Departemen Ilmu Kesehatan Mata Fakultas Kedokteran Universitas Padjadjaran/Pusat Mata Nasional RS Mata Cicendo Bandung, Jalan Cicendo No. 4 Bandung, E-mail: degamp@yahoo.com 


\section{Pendahuluan}

Dakriosistitis adalah merupakan penyakit sistem lakrimal yang sering ditemukan. Dakriosistitis adalahinflamasidarisakuslakrimalyang biasanya disebabkan oleh obstruksi duktus nasolakrimal. ${ }^{1}$ Obstruksi duktus nasolakrimal dapat merupakan inflamasi stenosis idiopatik (obstruksi duktus nasolakrimal primer didapat) ataupun sekunder akibat trauma, infeksi, inflamasi, neoplasma, ataupun obstruksi mekanik (obstruksi duktus nasolakrimal sekunder didapat). Obstruksi duktus nasolakrimal menyebabkan hambatan aliran air mata pada sistem aliran lakrimal sehingga menyebabkan dakriosistitis. ${ }^{2}$

Dakriosistitis dapat dijumpai pada semua usia. Manifestasi dakriosistitis dapat berupa infeksi akut maupun kronik. Dakriosistitis akut ditandai oleh adanya lakrimasi, sekret, pembengkakan yang lunak, nyeri, dan kemerahan di area sakus lakrimal di bagian bawah tepi atas tendon kantus medial. Dakriosistitis kronik dapat menimbulkan gejala ataupun tidak, namun umumnya tidak nyeri. $^{3}$

Data di Amerika Serikat menunjukkan bahwa dakriosistitis lebih sering terjadi pada wanita dibanding pria, dengan kelompok usia lebih banyak pada bayi dan dewasa usia lebih dari 40 tahun. Namun belum terdapat data epidemiologis tentang kejadian dakriosistitis di Indonesia. Tujuan penelitian ini adalah mengetahui jumlah kasus, karakteristik demografis, karakteristik klinis, dan penatalaksanaan dakriosistitis di Rumah Sakit Mata Cicendo pada rentang waktu 1 Maret 2014 hingga 30 September 2014.

\section{Metode}

Penelitian ini merupakan penelitian retrospektif deskriptif dengan mengambil data dari rekam medis seluruh pasien yang baru pertama kali terdiagnosis dakriosistitis di Rumah Sakit Mata Cicendo pada rentang waktu 1 Maret 2014 hingga 30 September 2014. Kriteria inklusi pada penelitian ini adalah semua pasien dakriosistitis yang baru pertama kali terdiagnosis di Rumah Sakit Mata Cicendo. Kriteria eksklusi adalah pasien yang telah terdiagnosis dakriosistitis sebelumnya dan pasien yang telah dilakukan penatalaksanaan dari sebelumnya yang terkait dakriosistitis di luar periode waktu penelitian. Data yang diteliti meliputi jumlah kasus, karakteristik demografis, karakteristik klinis dan penatalaksanaan dakriosistitis. Jumlah kasus, karakteristik demografis, karakteristik klinis dan penatalaksanaan dicatat dari rekam medis seluruh pasien yang terdiagnosis dakriosistitis dalam rentang waktu 1 Maret 2014 hingga 30 September 2014.

Karakteristik demografis pada penelitian ini adalah usia, jenis kelamin, dan lateralitas. Usia seluruh pasien dicatat dan juga dinilai rentang usia serta rata-rata usianya. Jenis kelamin dikelompokkan menjadi laki-laki dan perempuan.

Karakteristik klinis pada penelitian ini dibagi atas akut dan kronik berdasarkan atas tanda dan gejala penyakit. Dakriosistitis akut didiagnosis pada penderita dengan nyeri hebat, pembengkakan yang lunak, dan kemerahan pada area sakus lakrimal, berair ataupun terdapat sekret pada konjungtiva. Dakriosistitis kronik didiagnosis pada penderita dengan epifora persisten dan regurgitasi material mukoid atau mukopurulen pada saat area sakus lakrimal ditekan ataupun terdapat regurgitasi sekret mukoid atau mukopurulen pada irigasi drainase sistem lakrimal. ${ }^{2}$

Penatalaksanaan yang dicatat pada penelitian ini meliputi medikamentosa dan tindakan bedah berupa tindakan dacryocystorhinostomy (DCR). Data tersebut kemudian dianalisis interval kepercayaan untuk dapat menilai kemaknaan variabel masing-masing. Analisis ini dilakukan menggunakan komputer

\section{Hasil}

Pada penelitian ini ditemukan 13 pasien (13 mata) dengan diagnosis dakriosistitis. Sejumlah 12 dari 13 pasien perempuan dan hanya satu pasien laki-laki. Rentang usia penderita adalah 13 tahun hingga 71 tahun dengan rata-rata 41.3 tahun. Usia rata-rata penderita dakriosistitis akut adalah 42,29 tahun dengan rentang usia paling muda 13 hingga 71 tahun. Rata-rata usia penderita dakriosistitis kronik adalah 40,5 tahun dengan rentang usia 29 hingga 52 tahun. Dari 13 kasus, 7 kasus merupakan infeksi akut dan 6 kasus merupakan infeksi kronik dengan 1 pasien laki-laki merupakan infeksi kronik.

Sakus lakrimal kanan sudah terinfeksi pada empat orang pasien, sedangkan pada sakus lakrimal kiri terinfeksi pada sembilan orang pasien. Tidak ditemukan keterlibatan bilateral. Penatalaksanaan dakriosistitis ini dibagi atas medikamentosa dan tindakan bedah. Dua kasus infeksi kronik dilakukan tindakan bedah berupa dacryocystorhinostomy (DCR) pada saat kondisi infeksi sudah tenang. Sebelas kasus sisanya, baik 
Tabel 1 Karakteristik Penderita Dakriosistitis

\begin{tabular}{cc}
\hline Karakteristik & $\begin{array}{c}\text { Jumlah pasien } \\
\text { n (IK) }\end{array}$ \\
\hline Jenis Kelamin & \\
Laki-laki & $1(0-22 \%)$ \\
Perempuan & $12(77-100 \%)$ \\
Rentang usia & \\
$5-30$ tahun & $4(5-55 \%)$ \\
$31-60$ tahun & $8(34-87 \%)$ \\
$61-80$ tahun & $1(0-22 \%)$ \\
Lateralitas & \\
Mata kanan & $4(5-55 \%)$ \\
Mata kiri & $9(44-94 \%)$ \\
Kedua mata & - \\
\hline
\end{tabular}

Keterangan: IK: interval kepercayaan

infeksi akut maupun kronik, mendapatkan terapi medikamentosa.

Tabel 2 telah menampilkan hasil analisis perbandingan antara karakteristik penderita dakriosistitis akut dan dakriosistitis kronik. Pada variabel jenis kelamin tampak nilai interval kepercayaan antara perempuan dan laki-laki tidak memiliki perpotongan sehingga terdapat peluang adanya suatu perbedaan antar kedua sub variabel di mana perempuan dapat merupakan suatu faktor risiko terjadi pada dakriosistitis kronik. Variabel lain seperti rentang usia dan penatalaksanaan memiliki interval kepercayaan yang berpotongan satu sama lain sehingga tidak didapatkan perbedaan antar kedua sub variabel.

\section{Pembahasan}

Aparatus lakrimal ini terdiri atas aparatus sekretori dan juga ekskretori. Kelenjar lakrimal utama adalah kelenjar eksokrin yang terletak di kuadran seperior lateral orbita pada fossa kelenjar lakrimal. Kelenjar aksesori Krause dan Wolfring terletak di bagian dalam di antara forniks superior dan sedikit di atas tepi superior tarsus. Aparatus ekskretori terdiri atas punctum yang masing-masing dikelilingi oleh ampula, kanalikulus, sakus lakrimal, dan duktus nasolakrimal. Aparatus lakrimal bertanggung jawab terhadap pembentukan dan drainase air mata. ${ }^{4}$

Infeksi aparatus lakrimal yang paling sering dijumpai adalah dakriosistitis. Inflamasi sakus lakrimal memiliki berbagai macam penyebab, namun pada kebanyakan kasus faktor yang umumnya berperan adalah obstruksi total duktus nasolakrimal. Obstruksi duktus nasolakrimal menyebabkan stasis aliran air mata dan terjadi akumulasi air mata, sel-sel deskuamasi, dan juga sekresi mukus di bagian atas dari daerah obstruksi sehingga akan memberikan lingkungan yang baik untuk pertumbuhan infeksi sekunder bakteri. $^{2,4-5}$

Pada penelilitian ini terdiri atas 13 pasien dakriosistitis, 4 pasien berada pada rentang usia 5-30 tahun, 8 pasien berada pada rentang usia 31-60 tahun, 1 pasien berada pada rentang usia 61-80 tahun. Hal ini sesuai dengan penelitian

Tabel 2 Perbandingan Karakteristik Penderita Dakriosistitis Akut dan Dakriosistitis Kronis

\begin{tabular}{lcc}
\hline & Dakriosistitis akut (n=7) & Dakriosistitis kronis (n=6) \\
\hline Rentang Usia & 2 & 2 \\
$5-30$ tahun & 4 & 4 \\
$31-60$ tahun & 1 & - \\
61-80 tahun & & 5 \\
Jenis kelamin & 7 & 1 \\
Perempuan & - & \\
Laki-laki & & 4 \\
Penatalaksanaan & 7 & 2 \\
Non bedah & - & \\
Bedah (DCR) &
\end{tabular}

Keterangan: IK= interval kepercayaan; DCR= dacryocystorhinostomy 
yang dilakukan oleh Bharathi dkk. ${ }^{2}$ bahwa rentang usia terbanyak berada pada rentang usia 31-60 tahun.

Usia merupakan salah satu faktor presidposisi dakriosistitis akut. Beberapa penelitian dan kepustakaan telah menunjukkan bahwa penyakit ini seringkali didapatkan pada usia di atas 40 tahun dengan prevalensi tertinggi berada pada dekade kelima dan keenam. Penelitian Madhusudhan dkk. $^{9}$ memperlihatkan ratarata usia penderita dakriosistitis akut adalah 46,5 tahun.Pada penelitian ini, rata-rata usia penderita dakriosistitis akut yaitu 42,29 tahun. Terdapat kesamaan di antara dua penelitian ini yaitu sama-sama berada pada usia dekade keempat. ${ }^{6-8}$ Penelitian lain menunjukkan ratarata usia penderita dakriosistitis kronik adalah 50,5 tahun (rentang usia 16-91 tahun). ${ }^{10} \mathrm{Hal}$ ini serupa dengan penelitian yang dilakukan oleh Patel dkk. ${ }^{11}$ yang menunjukkan bahwa penderita dakriosistitis kronik banyak berada pada rentang usia 50-60 tahun. Pada penelitian ini rata-rata usia penderita dakriosistitis kronik adalah 40,50 tahun. Penelitian ini bila dibandingkan dengan penelitian yang dilakukan oleh Bhuyan adalah bersesuaian, yaitu para penderita dakriosistitis kronik banyak dijumpai pada rentang usia 4050 tahun.

Pada penelitian ini perempuan lebih banyak menderita dakriosistitis dibanding dengan lakilaki dengan perbandingan 12 orang perempuan (IK 77-100\%) dan satu orang laki-laki (IK 0-22\%). Predileksi jenis kelamin perempuan pada beberapa penelitian dan kepustakaan lebih banyak menderita dakriosistitis kemungkinan karena diameter kanal nasolakrimal yang lebih kecil pada perempuan dibandingkan laki-laki dan faktor hormonal. ${ }^{13-14}$

Penelitian yang dilakukan oleh Madhusudhan dkk. ${ }^{9}$ menyebutkan bahwa perempuan (17 dari 23) lebih banyak menderita dakriosistitis akut dibanding laki-laki (6 dari 23). Bharathi dkk. ${ }^{2}$ menyatakan bahwa perempuan lebih dominan menderita dakriosistitis, baik pada infeksi akut (433 dari 566) ataupun kronik (1072 dari 1325). Hal ini sesuai bila dibanding dengan penelitian yang dilakukan kali ini, yaitu semua penderita dakriosistitis akut adalah perempuan.

Perempuan merupakan faktor predisposisi terjadinya dakriosistitis kronik. Badhu dkk. ${ }^{15}$ melaporkan bahwa dari 662 pasien, sejumlah $67,6 \%$ pasien perempuan. Hal ini sesuai dengan penelitian ini bahwa perempuan (IK 69-100\%) lebih banyak menderita dakriosistitis kronik dibanding dengan laki-laki (IK 0-36\%) dan merupakan salah satu faktor resiko terjadinya dakriosistitis kronik. ${ }^{16}$

Pada penelitian ini keterlibatan mata unilateral pada semua kasus sesuai dengan penelitian yang dilakukan oleh Madhusudhan dkk. ${ }^{9}$ Keterlibatan mata kiri (IK 44-94\%) lebih banyak dibanding dengan mata kanan (IK 5-55\%) pada penelitian ini. Hal ini sesuai dengan penelitian lain yang dilakukan, yaitu keterlibatan sakus lakrimal kiri sebesar 58\%, dan Prakash dkk. ${ }^{13}$ dengan keterlibatan sebelah kiri (40\%) relatif lebih banyak dibanding kanan (32\%). ${ }^{17}$

Secara umum, dakriosistitis ini mempunyai predileksi pada sisi kiri, khususnya pada perempuan karena kanal yang lebih sempit. Duktus nasolakrimal dan juga fosa lakrimal membentuk sudut yang lebih besar pada sisi kanan dibanding kiri.

Dakriosistitis kronik lebih umum dijumpai dibanding dakriosistitis akut. Pada penelitian yang telah dilakukan oleh Madhusudhan dkk. ${ }^{9}$ insidensi kasus akut pada data demografis yang sedikit lebih tinggi dibanding dengan kasus kronik menunjukkan kemungkinan perubahan kecenderungan pada spektrum mikrobiologi dakriosistitis. Hal ini sesuai dengan penelitian ini, yang menunjukkan jumlah kasus akut ( 7 dari $13)$ sedikit lebih tinggi dibanding dengan kasus kronik (6 dari 13). ${ }^{16}$

Pedoman penatalaksanaan dakriosistitis akut, yaitu bahwa irigasi ataupun probing sistem kanalikuli tidak diperbolehkan hingga infeksi membaik, probing diagnostik maupun terapetik duktus nasolakrimal tidak diindikasikan untuk pasien dewasa dengan dakriosistitis yang akut, limitasi penggunaan antibiotik topikal, antibiotik oral efektif pada kebanyakan kasus, antibiotik parenteral untuk kasus berat, aspirasi sakus lakrimal bila terdapat pyocele-mucocele yang terlokalisir, abses terlokalisir yang melibatkan sakus lakrimal dan juga jaringan sekitarnya membutuhkan insisi dan drainase. Dakriosistitis yang mengindikasikan obstruksi total duktus nasolakrimal oleh karena keluhan epifora dan infeksi berulang membutuhkan tindakan DCR sebagai terapi definitif, dengan terlebih dulu mengkontrol infeksi yang terjadi. ${ }^{18-20}$

Pada penelitian ini ada dua kasus infeksi kronik dilaksanakan tindakan bedah berupa dacryocystorhinostomy (DCR) pada saat kasus infeksi sudah tenang. Sebelas kasus sisanya, baik infeksi akut maupun kronik, mendapatkan terapi medikamentosa. Penelitian ini memiliki keterbatasan, yaitu jumlah sampelnya yang sedikit. Keadaan ini terlihat pada rentang nilai interval kepercayaan yang sangat besar. Sehingga diperlukan penelitian lanjutan dengan 
memperhitungkan jumlah sampel yang sesuai agar dapat memberikan kemaknaan yang baik.

Simpulan, dakriosistitis dapat bermanifestasi akut maupun kronik. Perempuan lebih dominan usia 41,3 tahun. Penatalaksanaan dakriosistitis akut dilakukan dengan terapi medikamentosa. Terapi definitif dakriosistitis kronik adalah dengan tindakan DCR pada saat kondisi infeksi sudah tenang.

Saran, diperlukan penelitian prospektif yang lebih lanjut dengan jumlah sampel yang lebih besar dengan analisis faktor risiko untuk mendapatkan data yang mewakili populasi dan dapat digunakan sebagai panduan klinis seharihari.

\section{Daftar Pustaka}

1. Shah CP, Santani DA. Comparative bacteriological profile and antibiogram of dacryocystitis. Nepal J Ophthalmol. 2011; 3(6):134-9.

2. Bharathi MJ, R Ramakrishnan, V Maneksha, C Shivakumar, V Nithya, S Mittal. Comparative bacteriology of acute and chronic dacryocystitis. J Eye. 2008;22(7):953-60.

3. Shakya DK, Gandhi S, Adlakha N, Kujur $\mathrm{R}$, Chauhan HRS, Ranjan KP. A clinicobacteriological study of lacrimal regurgitate in cases of chronic dacryocystitis in a referral hospital in Madya Pradesh. Int J Med Public Health. 2015;5(4):270-3.

4. American Academy of Ophthalmology. Development, anatomy, and physiology of the lacrimal secretory and drainage system. Chapter 12. Dalam: American Academy of Ophthalmology, penyunting. Edisi ke7. Orbit, Eyelids, and Lacrimal System. Singapore: AAO; 2011. hlm. 243-6.

5. Pradeep AV, Satish SP, Koti SV, Arunkumar JS, Santosh SG, Jyotirmay SH. Clinicobacteriological study of chronic dacryocystitis cases in Northern Karnataka, India. J Clin Diagn Res.2013;7(11):2502-4.

6. Pinar-Sueiro $S$, Mercedes $S$, TelmoXabier L, Ane G, Bárbara C, Begoña V, dkk. Dacryocystitis: Systematic approach to diagnosis and therapy. Curr Infect Disease Rep.2012;14(2):137-46.

7. Disorders of the lower lacrimal system. Dalam: Lang GK, penyunting. Ophthalmology. A pocket textbook atlas. Edisi ke-2. New York: Thieme Stuttgart; 2006. hlm. 57-9.

8. Kandati J, Kumar GK, Avanish G, Buchineni M, Pathapati RM, Srinivas P. Microbial surveillance of acute and chronic dacryocystitis in a tertiary care hospital. J Evolution Med Dental Sci. 2015;4(3):40815.

9. Madhusudhan, Muslikan Y, Ismail N, Hussein A. Microbiological aetiology of acute dacryocystitis in hospital Universiti Sains Malaysia, Kelantan Malaysia. J Acute Dis. 2012;1(1):31-4.

10. Eshraghi B, Abdi P, Akbari M, Fard MA. Microbiologic spectrum of acute and chronic dacryocystitis. Int J Ophthalmol. 2014;7(5): 864-7.

11. Patel K, Renu M, Sarika S, Abhay L, Atreyee P, RN Misra. A clinico-bacteriological study of chronic dacryocystitis. Sudanese J of Ophthalmol. 2014;6(1):1-5.

12. Shakya DK, Gandhi S, Adlakha N, Kujur R, Singh Chauhan HR, Ranjan KP. A clinicobacteriological study of lacrimal regurgitate in cases of chronic dacryocystitis in a referral hospital in Madhya Pradesh. Int J Med Public Health. 2015;5(4):270-3.

13. Prakash R, Girish B, Nagaraj E, Prashanth $\mathrm{H}$, Jayashree S. A bacteriological study of dacryocystitis. J Clin Diagn Res. 2012;6(4): 652-5.

14. Majidaee M, M. Mohammadi, MR Rezaee S, M Khademlu, and MA Heidari G. Patients undergoing dacryocystorhinostomy surgery in Northern Iran: an epidemiologic study. Ann Med Health Sci Res. 2014;4(3):365-8.

15. Badhu BP, Karki BS, Khanal B, Dulal S, Das $\mathrm{H}$. Microbiological patterns of chronic dacryocystitis. Ophthalmology. 2006; 113(12):2377.

16. Ali MJ, Motukupally SR, Joshi SD, and Naik MN. The microbiological profile of lacrimal abcess: two decades of experience from a tertiary eye care centre. J Ophthalmic Inflamm Infect. 2013;3(1):57-62.

17. American Academy of Ophthalmology. Abnormalities of the lacrimal secretory and drainage systems. Chapter 13. Dalam: American Academy of Ophthalmology, penyunting. J Orbit, Eyelids, and Lacrimal System. Edisi ke-7. Singapore: AAO; 2011. hlm. 275-6.

18. Okumuş S, Öner, Durucu C3, Coşkun E, Aksoy Ü, Durucu E, dkk. Nasolacrimal duct intubation in the treatment of congenital nasolacrimal duct obstruction in older children. Eye (Lond). 2016;30(1):85-8.

19. Wu W, Yan W, MacCallum JK, Tu Y, Jiang $\mathrm{AC}$, Yang $\mathrm{Y}$, dkk. Primary treatment of acute dacryocystitis by endoscopic 
M. Rinaldi Dahlan: Karakteristik Penderita Dakriosistitis di Pusat Mata Nasional Rumah Sakit Mata Cicendo

dacryocystorhinostomy with silicone intubation guided by a soft probe. Ophthalmology. 2009;116(1):116-22.

20. Baskin DE, Reddy AK, Chu YI, Coats DK.
The timing of antibiotic administration in the management of infant dacryocystitis. J AAPOS. 2008;12(5):456-9. 